DOI 10.15290/cnisk.2017.01.02.08

DR MAGDALENA EL GHAMARI

Uniwersytet w Białymstoku

\title{
Muzułmanki z Instagrama - modowe trendy kulturowe współczesnych kobiet z kręgu kultury arabsko-muzułmańskiej
}

Streszczenie

Stosunek do praw kobiet $\mathrm{w}$ islamie jest nierozerwalnie zwiazany z koncepcja rodziny i społeczeństwa jako całości. Prawo wywodzi się wprost $z$ religii i podporząlkowane jest celom szariatu. Istotne sa różnice w podejściu do kwestii praw kobiet w islamie i powstałych na Zachodzie międzynarodowych aktów prawnych regulujących kwestie praw człowieka. Podstawowa różnica polega na tym, że szariat nie gwarantuje automatycznie równości płci, ochrony praw kobiet i walki $z$ dyskryminacją.

Koncepcja równości $\mathrm{w}$ islamie ma swoją religijna specyfikę. W kulturze muzułmańskiej sfery prawa i religii sa nierozdzielne i uzgodnione w taki sposób, że nie sposób naruszyć zapisów prawa boskiego, nie naruszając jednocześnie prawa stanowionego.

Różnice w dostępie do równych praw dla kobiet muzułmańskich wynikaja ze specyfiki lokalnych kultur i tradycji religijnych. Większość krajów muzułmańskich stosuje dzisiaj wobec kobiet normy szariatu w mniej lub bardziej ograniczonym zakresie, który różni się w zależności od obszaru.

Słowa kluczowe: Arabki $\cdot \operatorname{muzułmanki} \cdot \operatorname{moda} \cdot$ portale społecznościowe $\cdot$ blogi 


\title{
MUSLIM WOMEN FROM INSTAGRAM - FASHION TRENDS IN CONTEMPORARY ARAB - MUSLIM CULTURES
}

\begin{abstract}
The contemporary situation of Muslim women is different in different parts of the Islamic world - it cannot be clearly defined as good or bad. It is not only the result of the division of societies into rich and poor, because in the rich countries of the Gulf, women enjoy less freedom than in many poor villages in Syria. The position of Muslim women in the world raises a lot of controversy as a result of cultural prejudices or ignorance.

General trends in the fashion world do not omit men and women in Muslim countries. Like other young people all over the world they are directly exposed to changing trends, including those known as "Western wear".

It can be said that the modern activities of Muslim women that fit their - interests give them a new type of professional experience and consequently lead to their economic independence. These activities and interests don't conflict with traditional roles a Muslim woman plays in the family. Online shopping, for example, can be done without leaving the office or while keeping an eye on the house and children.

Keywords: Arab women • Muslim women • fashion • social network - blogs

Współczesna sytuacja kobiet muzułmańskich jest odmienna w różnych częściach świata islamu - nie da się jej jednoznacznie zdefiniować jako dobrą bądź złą. Nie jest to tylko rezultat podziału na społeczeństwa bogate i biedne, gdyż w bogatych krajach Zatoki Perskiej kobiety maja mniej wolności niż w biednej wiosce w Syrii. Mimo to pozycja kobiet muzułmańskich budzi w świecie wiele kontrowersji, często opartych na kulturowych uprzedzeniach, niekiedy wynikających $z$ niewiedzy.

O kobiecie muzułmańskiej można mówić od chwili, w której wydostała się z dżahilijji, epoki niewiedzy i ciemności poprzedzajacej islam. Okres ten sięga niepamiętnych czasów - od przełomu
\end{abstract}


VI/VII w. do około ery muzułmańskiej. Kobieta tego okresu jest pewnym uogólnieniem, ponieważ oznacza różne typy kobiet żyjacych w „niewiedzy”, której kres położył islam. W schyłkowym okresie dżahilijji pozycja kobiet znacznie wzrosła. W niektórych plemionach przybierała ona postać matriarchatu. To matka decydowała o losach rodziny - urodzone dziewczynki dziedziczyły władzę po matce. Dorastając, cieszyły się większą bądź mniejszą swobodą seksualna, zdarzały się im przedślubne czy pozamałżeńskie romanse, a dzieci $z$ takich związków nie przynosiły ujmy. Wychodząc za mąz, kobieta oczekiwała na sodak - zwyczajowy prezent ślubny obejmujący słodycze, odzież, pieniądze, wielbłądy czy inne atrakcyjne dobra. Praktykowana była również poliadria ${ }^{1}$. Istniał zwyczaj, zgodnie $z$ którym kobieta mogła mieć dziesięciu mężów. Matka żyjąca według tradycji matriarchalnej miała wiele praw i odgrywała dużą rolę zarówno w swoim małżeństwie, jak i w społeczności. Nie piętnowano jej za zdradę małżeńska, mąż mógł jej owa zdradę wybaczyć. Postawy matriarchalne dawały o sobie znać na Półwyspie Arabskim do końca dżahilijji, a jeszcze na styku tej epoki $z$ islamem żyły w Mekce przedsiębiorcze kobiety, które same prowadziły swoje interesy, zarządzały majatkiem i wybierały sobie mężów. Jednakże na początku ery islamskiej rola kobiety muzułmańskiej uległa całkowitej zmianie. Od tej pory zaczał dominować typ kultury męskiej, który doprowadził kobietę do skrajnego uprzedmiotowienia. Urzeczowiona kobieta nie posiadała niczego, nie miała prawa do majątku bądź jakiejkolwiek własności - to ona stawała się własnością, gdyż po śmierci męża wdowę wraz $z$ całym dobytkiem dziedziczył jego brat. Nie miała prawa domagać się satysfakcji emocjonalnej i intelektualnej; jej przeznaczeniem było małżeństwo, o którym decydował ojciec.

Mniej więcej od lat dziewięćdziesiątych XX w. na wygląd muzułmanek wpływ ma swoista moda. Jej kanony kształtuja projektantki, które niejednokrotnie w swoich własnych domach organi-

1 Wielomęstwo - jedna $z$ form poligamii, kiedy jedna kobieta ma kilku mężów jednocześnie, przy czym żaden $z$ jej mężów nie ma w tym samym czasie innej żony. 
zują pokazy strojów godzących religię i nowoczesność, skromność $z$ odrobina fantazji. Modne panie śledza propozycje kolorowych magazynów, które nie tylko podaja co nosić, ale i jak się zachować, dbając o religijność. Na potrzeby kobiecych pism do sesji zdjęciowych nierzadko wykorzystuje się manekiny. Zdarza się prezentować ubiory na prawdziwych modelkach, pokazywanych jednak od szyi w dół. Do niedawna powszechne było komputerowe rozmazywanie twarzy pozujacych pań.

Nowoczesne konsumentki chętnie korzystaja $z$ usług salonów urody tylko dla zawoalowanych klientek. Zamawiaja każdy luksusowy zabieg. W ofercie nie ma jedynie czesania włosów - pięknie ułożona fryzura mogłaby kusić do wyjścia na ulicę bez hidżabu.

Hidżab jest sposobem ubierania. Kobieta powinna zakrywać całe swoje ciało oprócz twarzy i dłoni. Tylko maż ma przywilej oglądania żony w pełnej krasie. Dlatego w miejscach publicznych zakładają one długie spodnie, do tego najczęściej lekki płaszczyk do kolan $z$ długimi rękawami oraz chustkę na głowę. Dziewczynki powinny ubierać się w ten sposób od ukończenia 9. roku życia.

Zamożne mieszkanki państw muzułmańskich, tzw. muhajababes (muhadżdżaba - nosząca hidżab, babes - ślicznotki), maja w szafie zarówno obcisłe, stylowe stroje, jak i dopasowane do nich hidżaby. Wiedza, że liczy się świeżość, nowoczesność, oryginalność i wartość wyrażona metką. Demonstracja statusu materialnego nie jest mniej ważna dla szczelnie zawoalowanych mieszkanek krajów Zatoki Perskiej. Lśniące buty od znanych projektantów, abaja (szeroki, luźny płaszcz) z wysokogatunkowej tkaniny i zasłona na twarz odróżniaja je od znacznie mniej zamożnych imigrantek.

$Z$ perspektywy badanej tematyki niezwykle istotna jest również rola transferu kulturowego w dzisiejszym świecie. Współczesne Arabki muzułmanki mają bardzo różne oblicza, dlatego nie wolno w tej kwestii generalizować. Inaczej będą wyglądać kobiety $z$ biednych obszarów wiejskich, inaczej zaś te $z$ bogatych krajów Zatoki Perskiej. Rozpiętość ich możliwości jest definiowana za- 
równo statusem materialnym, jak i miejscem urodzenia. Aczkolwiek modowe trendy zwiazane sa $z$ ważnym aspektem transferu kulturowego jako efektu globalizacji.

Transfer kulturowy narodził się w latach osiemdziesiatych $\mathrm{XX} \mathrm{w.}{ }^{2} \mathrm{~W}$ badaniu tego zagadnienia ogromna rolę odegrali intelektualiści - Michel Espagne, Matthias Middell i Michael Werner. Związane to było $z$ porzuceniem narodowej perspektywy postrzegania i wyjścia $\mathrm{w}$ kierunku badania współzależności zachodzacych w kulturze zjawisk.

Transfer kulturowy zdefiniować można jako przemieszczanie się obiektów materialnych i idei oraz symboli w obrębie różnych kultur. Mamy więc punkt startu, nieraz trudny do ustalenia, przenoszoną treść, a także punkt docelowy. Co istotne, ważna jest nie tylko kultura będaca "nadawca”, ale i ta stanowiąca „adresata”. To ona „odbiera” przekaz na swój sposób, poprzez pryzmat swoich cech. Często też przetwarza obcy produkt. Nie jest zatem bierna, bierze udział $\mathrm{w}$ kreowaniu nowych znaczeń. Toteż wymiana ma charakter dwustronny lub nawet wielostronny, a niejednokrotnie, choć niekoniecznie, symultaniczny ${ }^{3}$.

$\mathrm{Na}$ intensyfikację transferu kulturowego wpływ ma także rosnąca fala migracji. Imigranci, $z$ którymi stykaja się rdzenni mieszkańcy danego miejsca, często przeszczepiaja swoje rodzime tradycje na obcy grunt. Wielu ludzi wychowuje się na styku odmiennych kultur kraju rodzimego i zamieszkania bądź różnego pochodzenia rodziców. Sa to dzieci imigrantów czy też te $z$ tzw. związków mieszanych. Tworzy się strefa pewnego rodzaju „pogranicza”. Wokól zachodnich miast wyrastaja etniczne przedmieścia, których mieszkańcy codziennie lawiruja między różnymi kulturami, $z$ większym lub mniejszym sukcesem łącząc ich elementy - adaptując się w węższym albo szerszym zakresie. Dziś transfer kulturowy w znacznej mierze umożliwiają także środki

2 L. Jurek, Teoria transferu kulturowego $i$ jej zastosowanie $w$ badaniach historii społecznej (na przykładzie polsko-włoskich kontaktów doby Risorgimento), „Studia $z$ Historii Społeczno-Gospodarczej XIX i XX wieku" 2009, t. 6, s. 1.

3 German Culture in Nineteenth-century America: Reception, Adaptation, Transformation, red. L. Tatlock, M. Erlin, New York 2005, s. 107. 
masowego przekazu. Tak naprawdę, aby w jakimś zakresie przyswoić sobie obce wzorce kulturowe, nie trzeba już ruszać się $z$ domu. Prasa, telewizja i oczywiście wyjątkowe narzędzie, jakim jest Internet, umożliwiaja kontakt $z$ odmiennymi kulturowo modami czy ideami poprzez ich oglądanie, analizowanie i ewentualne przetwarzanie.

Najwięcej kontrowersji budzi zetknięcie się świata niemuzułmańskiego $z$ zasłonami muzułmanek. Kobiety $\mathrm{w}$ hidżabach, a nawet burkach, stały się już bowiem stałym elementem krajobrazu ulic wielu europejskich miast. Przy czym im bardziej dana kobieta jest zakryta, tym większą dyskusję wzbudza jej strój.

Poza krajem muzułmańskim kobieta w zasłonie często staje się nagle symbolem zupełnie innych idei: zagrożenia terrorystycznego, uwstecznienia społeczeństw muzułmańskich, pogwałcenia praw kobiet, ostentacyjnym symbolem religijnym. Próbujac przybliżyć temat $z$ perspektywy muzułmańskiej, posłużę się tu omówieniem, którego dostarcza ulotka malezyjskiej organizacji IPSI (ang. Islamic Propagation Society International) pt. The Burqa \& Niqab. Uncovering the facts. Prezentuje ona, punkt po punkcie, różne powszechne opinie dotyczące zasłon, zdaniem autorów często niesłuszne. Tymczasem to właśnie na ich podstawie wiele krajów zamierza na drodze prawnej zakazać noszenia zasłon.

Po pierwsze, wiele osób uważa, że noszenie przez kobietę zasłony jest jej zawsze narzucone siła i stą opresyjne. Świat Zachodu, który deklaruje przywiazanie do wolności jednostki, strój narzucony, nawet jeśli jest takowym na drodze osobistych przekonań religijnych, postrzega często jako ucisk i przykry obowiazek. Oczywiście nie ma wątpliwości, że w wielu wypadkach dzieje się i tak, że kobieta zmuszana jest do założenia zasłony przez inną osobę lub społeczność. Nie można jednak ignorować faktu, że wiele spośród nich podejmuje taką decyzję w pełni samodzielnie, nierzadko też wbrew bliskim, w tym mężczyznom $z$ rodziny. Muzułmanie stawiaja $\mathrm{w}$ tym miejscu pytanie, czy prawdziwa opresja nie jest natomiast zakazywanie muzułmankom noszenia zasłon, 
jeśli uważaja je one za ważny element swoich przekonań religijnych czy tożsamości?

Chusta $\mathrm{w}$ krajach $\mathrm{z}$ przeważająca większością chrześcijan, których co do zasady w głównym nurcie nie obowiazuja żadne charakterystyczne wymogi wobec stroju, bywa również odczytywana jako agresywny i ostentacyjny manifest innej wiary.

Pojawiaja się też głosy, że zasłony są czymś wstecznym, elementem przynależącym do odległej przeszłości, kojarzonym z zacofaniem. Muzułmanie podkreślaja jednak, że chusta sama w sobie traktowana jest przede wszystkim jako element religijny, a nie ostatni krzyk mody. Jako taka powinna być zatem postrzegana jako coś ponadczasowego. Zachód często na podstawie zmian zachodzacych w strojach kobiet danego kraju wyciaga daleko idace wnioski z zakresu jego bieżącej sytuacji politycznej czy socjologicznej. Niejednokrotnie rzeczywiście można w ten sposób opisywać pewne szersze tendencje, ale narzucanie zasłonie znaczenia symbolu zacofania jest już zupełnie inną kwestia.

$\mathrm{Na}$ tej podstawie opiera się dysonans, jaki przeżywa człowiek Zachodu, widzac pania profesor, wykwalifikowana lekarkę lub inną specjalistkę $\mathrm{w}$ zasłonie. Wbrew opinii, że zasłonięta kobieta sprowadzona jest do roli anonimowego przedmiotu, wielu $z$ nich to właśnie taki strój umożliwia aktywny udział w życiu społecznym czy dostęp do kształcenia.

Co więcej, w niektórych państwach zachodnich na fali transferu kulturowego następuje też adaptacja hidżabu jako części oficjalnego stroju służbowego dla muzułmanek, np. brytyjskich policjantek. Nie wiadomo jednak, czy kobieta nosząca na co dzień hidżab zdecydowałaby się na karierę w policji, gdyby musiała go zdejmować do munduru.

Transfer kulturowy nie musi polegać na stereotypowym odbieraniu obcych kulturowo elementów, gdy pojawiaja się one na "cudzym gruncie". Jak już zostało to wspomniane we wstępie, często przyczynia się on także do powstania pewnej „nowej jakości" na skutek przetwarzania i dostosowywania. 
Fotografia 1,2. Lalki Fulla
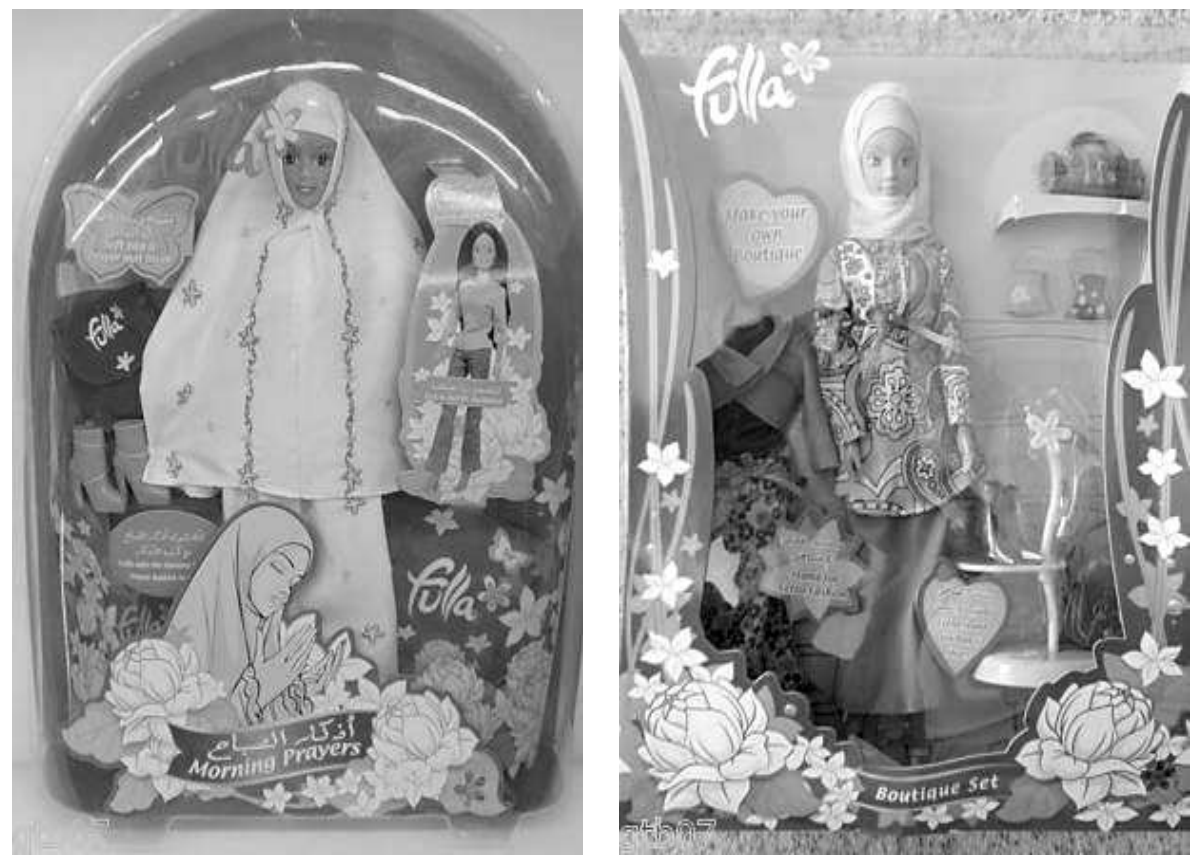

Źródło: https://www.alibaba.com/showroom/fulla-doll.html [dostęp: 27.01.2017].

Przykładem wytworu transferu kulturowego jest Fulla, muzułmańska "siostra Barbie”, produkowana przez firmę NewBoy $z$ Dubaju. Stworzona na wzór Barbie, będącej wręcz symbolem zachodniej kultury. Fulla, podobnie jak jej protoplastka, stanowić ma dobry wzorzec zachowań dla bawiących się nią dziewczynek. Toteż jej ubrania sa skromne, a w komplecie często dodawany jest hidżab. Nawet jeśli lalka ma na sobie suknię balowa. Kupić można również Fullę w stroju do modlitwy. Powstała także cała specjalna linia lalek $w$ tradycyjnych strojach $z$ różnych krajów muzułmańskich, będąca ciekawym świadectwem bogactwa kręgu kultury islamu. Również w zakresie tak ważnego elementu stroju, jakim jest biżuteria, mamy do czynienia ze zjawiskiem transferu kulturowego. 
Fotografia 3,4. Lalki Fulla w różnych odsłonach
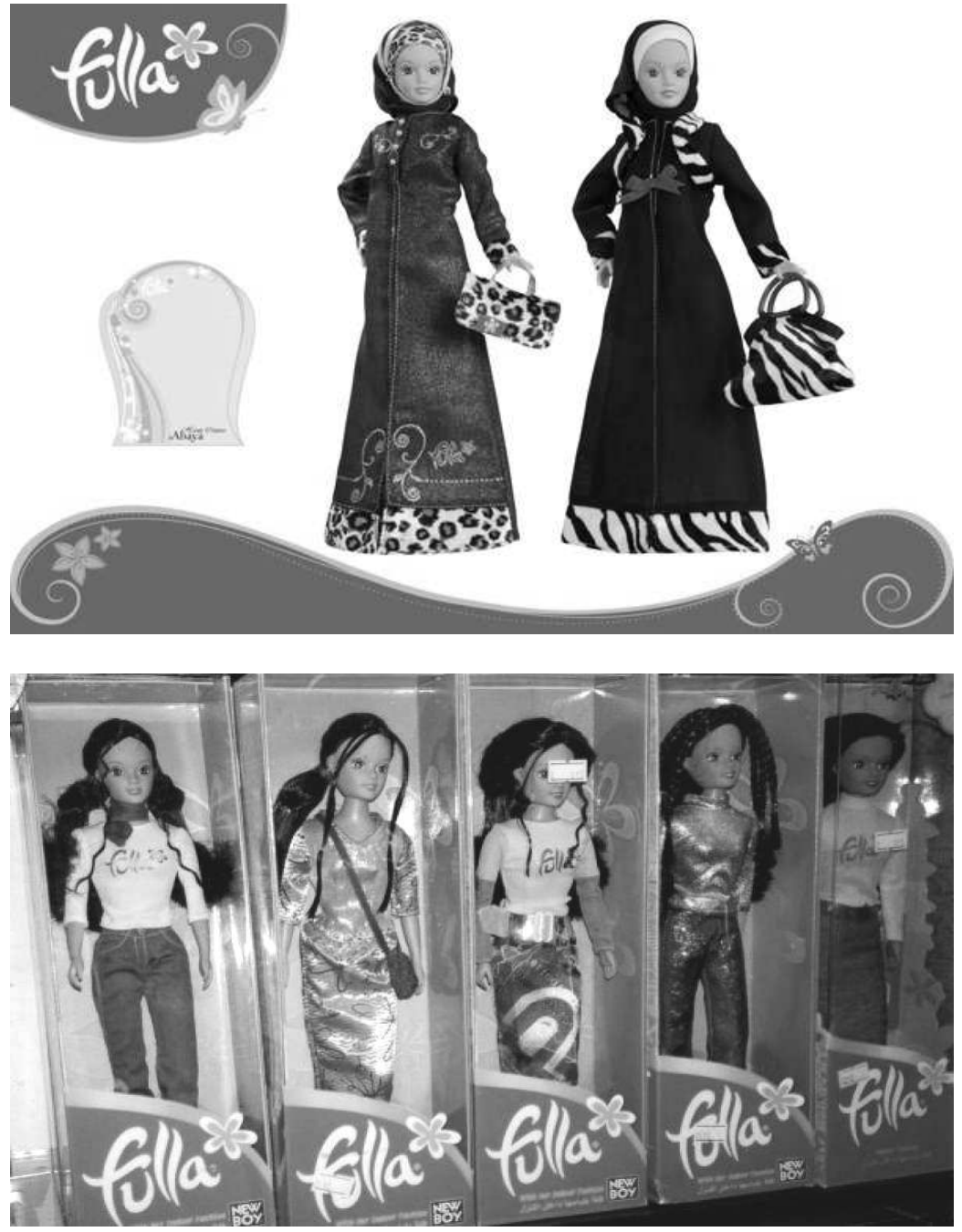

Źródło: https://www.alibaba.com/showroom/fulla-doll.html [dostęp: 27.01.2017].

Wielkie domy mody, jak Dolce \& Gabbana, w swoich liniach produktów dla klientek muzułmanek łączą cechy swojej marki, wypracowane na modelach „zachodnich”, z elementami strojów 
dla muzułmanek ${ }^{4}$. Powstaja charakterystycznie dekorowane abaje czy hidżaby $z$ logo znanych marek.

Fotografia 5,6. Kolekcja Dolce \& Gabbana dla muzułmanek
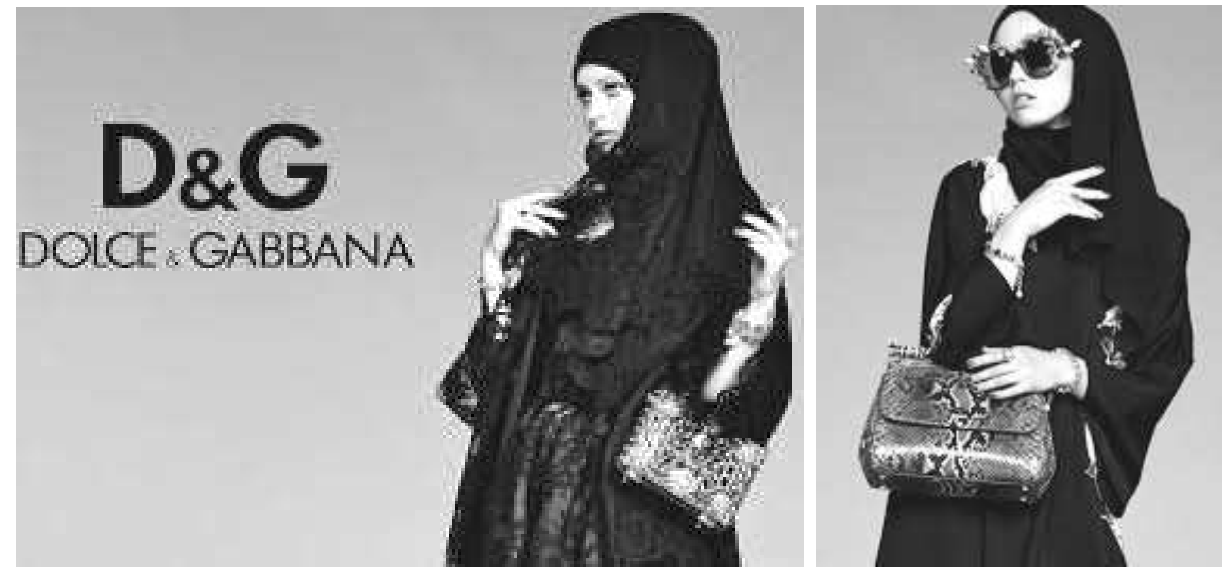

Źródło: http://lirisimplebeauty.com/?p=1346 [dostęp: 27.01.2017].

Kolejnym znanym i cenionym projektantem jest John Galliano, który szyje abaje na miarę, a ich wartość sięga 10 tys. dolarów. Trafiaja one do sklepów $\mathrm{w}$ saudyjskich miastach Jeddah i Rijad. Na zakupy z wyższej półki pozwalają sobie saudyjskie księżniczki, które w Saks kupuja kilkanaście wieczorowych sukni naraz. Każda $z$ nich kosztuje mniej więcej 20 tys. dolarów. Jak powiedział Mahammed Nafisa, na miejsce każa sobie przywozić części $z$ najnowszych kolekcji $z$ Mediolanu i Paryża, ponieważ chca mieć abaje wykonane przez tych samych projektantów, by pasowały do sukni. Dodał też, że strój taki założą raz na wieczorne przyjęcie, na którym będa same kobiety 5 .

Kolejnym przykładem jest projektantka Hind Beljafta, która specjalizuje się w wytwornych wersjach czarnych abaji dla za-

${ }^{4}$ Dolce \& Gabbana's Embellished Hijabs and Abayas Are Great News for Muslim Women - When Will Other Brands Follow Suit?, red. S. Yotka [Dostęp: 05.01.2017]. Dostępny w World Wide Web: <http://bit.ly/2qA8jJ2>.

5 Ibidem. 
możnych kobiet $z$ Zatoki Perskiej, ukrywających kształt kobiecego ciała. Przy projektowaniu wykorzystuje hafty, palmy w różnych kolorach czy metalowe i skórzane ćwiekí. Klientki zgłaszają się do jej firmy i proszą o stworzenie abaji, które będą pasować do modnych butów na wysokim obcasie czy torebek takich marek, jak Hermes, Channel, Gucci lub Christian Dior. Wynika to $z$ faktu, iż, bywając w miejscach publicznych, nie moga pokazać swojego ubioru i musza mieć założoną abaję. Jak mówi Tamara Al Gabbani, kobieta biznesu $z$ Dubaju i prezenterka telewizyjna, $w$ modnych abajach czuje sie jak nowoczesna arabska kobieta. Zakładanie abaji zawsze było częścia mojego stylu życia. Jak widać, dzisiejsze pokolenie muzułmanek chce czegoś nowego, szuka swojego stylu. Współczesna arabska, majętna kobieta jest wykształcona, prowadzi czynne życie i pracuje, dlatego chce zachować swoja tożsamość, wyglądając przy tym modnie. Zdaniem Alberty Ferretti, projektantki mody z Mediolanu, moda islamska ma potencjat, który nie został do końca oszacowany?.

Należy pamiętać, że świat mody to nie tylko rynek zachodni. Rozszerza się on $z$ Bliskiego Wschodu po zamieszkałe przez muzułmanów kraje południowo-wschodniej Europy, Ameryki Północnej, Afryki i Azji. Świadectwem popularności może być Festiwal Mody Islamskiej (ang. Islamic Fashion Festival), który odbywa się cyklicznie w czerwcu każdego roku, poczynając od 2006 r. (w Dżakarcie i Kuala Lumpur), w 2008 r. docierajac do Dubaju. Światowej sławy projektantka Data Raja Rezza chce doprowadzić do tego, by te trzy miasta stały się stolicami mody muzułmańskiej, tak jak Paryż, Mediolan i Nowy Jork sa światowymi wizytówkami mody zachodniej ${ }^{8}$. Na głównej stronie Islamic Fashion Festival czytamy, że jego głównym celem jest zdobycie serc i umysłów muzułmanów i niemuzułmanów. Organizatorzy obalają przestarzałe mity, przez swoje świeże pomysły wzbudzając zainteresowanie i ciekawość wszystkich środowisk, dzięki czemu ludzie

${ }^{6}$ H. Meyer, H. Couch, Harrods liczy na zyski $z$ islamskiej mody [Dostęp: 20.01.2017]. Dostępny w World Wide Web: <http://bit.ly/2rpyb9N>.

7 Ibidem.

8 Ibidem. 
chca się dowiedzieć więcej zarówno na temat nowych trendów modowych w tym obszarze świata, ale i samej religii.

Festiwal Mody Islamskiej dzięki swojej interpretacji i twórczości projektantów pokazuje, jak dynamicznie rozwija się moda muzułmańska. Poprzez pokazy mody aspiruje do ukazywania wielowymiarowych aspektów islamu, który będzie pobudzał interakcje między wszystkimi narodami. Zamysłem festiwalu jest ustawienie islamskiej mody jako istotnego gracza na arenie międzynarodowej. Misja jest również budowanie świadomości i uznania dla wrodzonego piękna oraz różnorodności mody kultury islamskiej, jak również skierowanie uwagi mediów w kierunku ducha islamu. Zachęcenie muzułmanów i niemuzułmanów w urzekający sposób, by zwrócić ich uwagę na różnorodność i ekspresję w islamskiej modzie ${ }^{9}$.

Fotografia 7. Festiwal Mody Islamskiej

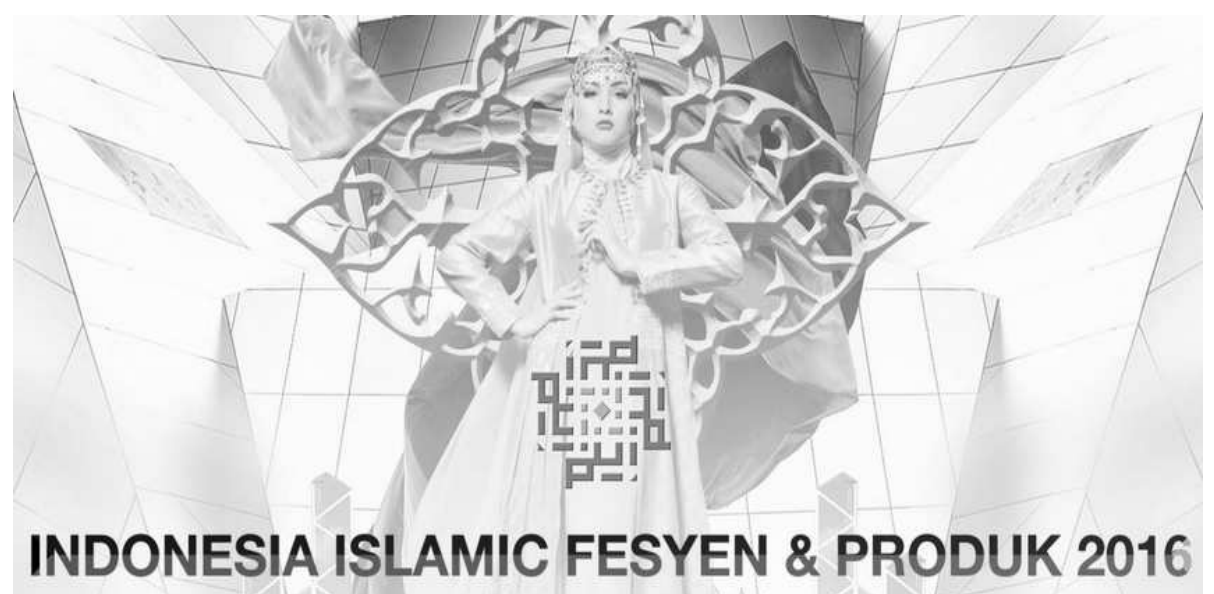

Źródło: https://www.facebook.com/JIIFFest/ [dostęp: 27.01.2017].

9 International Islamic Fashion Festival, Discover the beauty of modesty [Dostęp: 05.01.2017]. Dostępny w World Wide Web: <http://bit.ly/2r16KvN>. 
Fotografia 8. Festiwal Mody Islamskiej

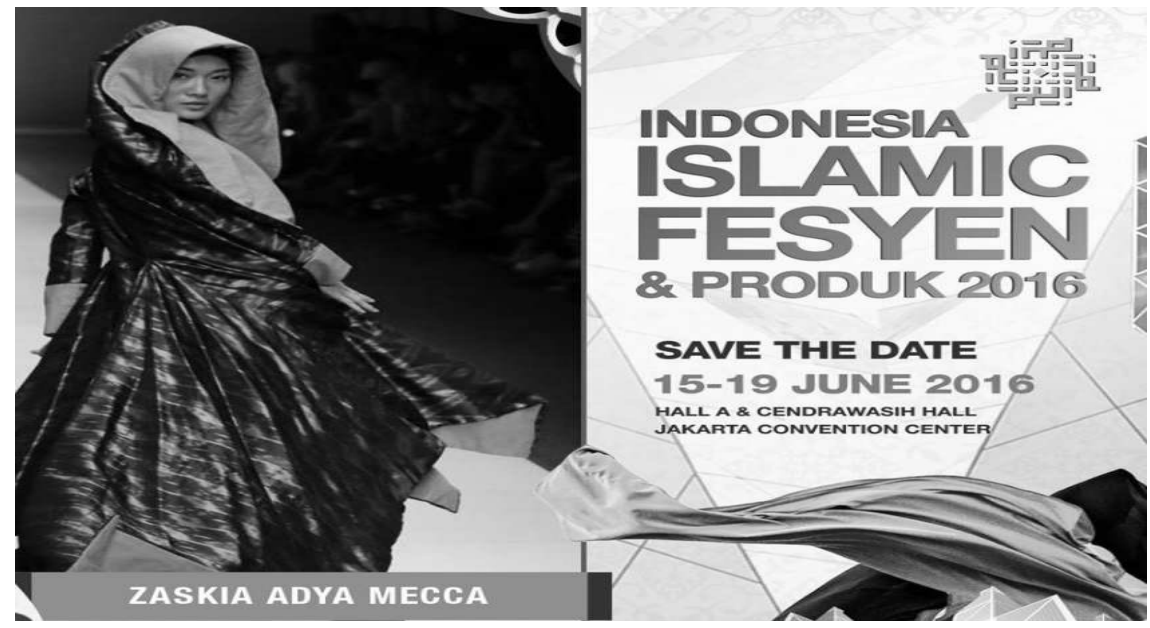

Źródło: https://www.facebook.com/JIIFFest/ [dostęp: 27.01.2017].

Hasło festiwalu „Odkryj piękno skromności” zaprasza publiczność do poznania, docenienia i zrozumienia zakrywania kobiet $\mathrm{w}$ islamie ${ }^{10}$. Co więcej, organizatorzy zapewniaja, że jest ono zgodne $\mathrm{z}$ zasadami religii. Promuje muzułmańska kulturę oraz ekspresję i kreatywność w zarezerwowanej dla zachodnich projektantów dziedzinie, przynajmniej według stereotypów.

Arabki muzułmanki są również obecne na portalach społecznościowych, prowadza też swoje blogi, przez co aktywnie uczestnicza $\mathrm{w}$ wirtualnym świecie. Jednym $\mathrm{z}$ przykładów jest pół-Kuwejtka, pół-Amerykanka Ascia Al Faraj, w Internecie Ascia AKF, która stworzyła swojego bloga w 2012 r. Jak sama mówi, nie podobało jej się to, że do tamtego czasu większość kobiet muzułmanek obecnych w Internecie, na Twitterze czy Instagramie, przy okazji prezentowania mody „ucinało” na zdjęciach swoje głowy, co miało uniemożliwić ich identyfikację. Ascia jako jedna $z$ pierwszych blogerek nie ukrywała swojej twarzy. Na pewno w tej decyzji pomógł jej mąż, który w pełni zaakceptował to zajęcie, a nawet angażuje się $\mathrm{w}$ jej działania i występuje publicznie $\mathrm{u}$ jej

10 Ibidem. 
boku11. Także mieszkająca w Szwecji Tunezyjka Miariam Ayari fotografuje się na Instagramie $z$ mężem i dzieckiem ${ }^{12}$. Trzeba jednak przyznać, że nie jest to norma i takie blogi należą do rzadkości.

Z zupełnie innych względów oryginalna jest grupa blogów poświęcona całkowicie nowatorskiemu nurtowi „muslim lolita”13.

Fotografia 9, 10. „Muslim lolita”
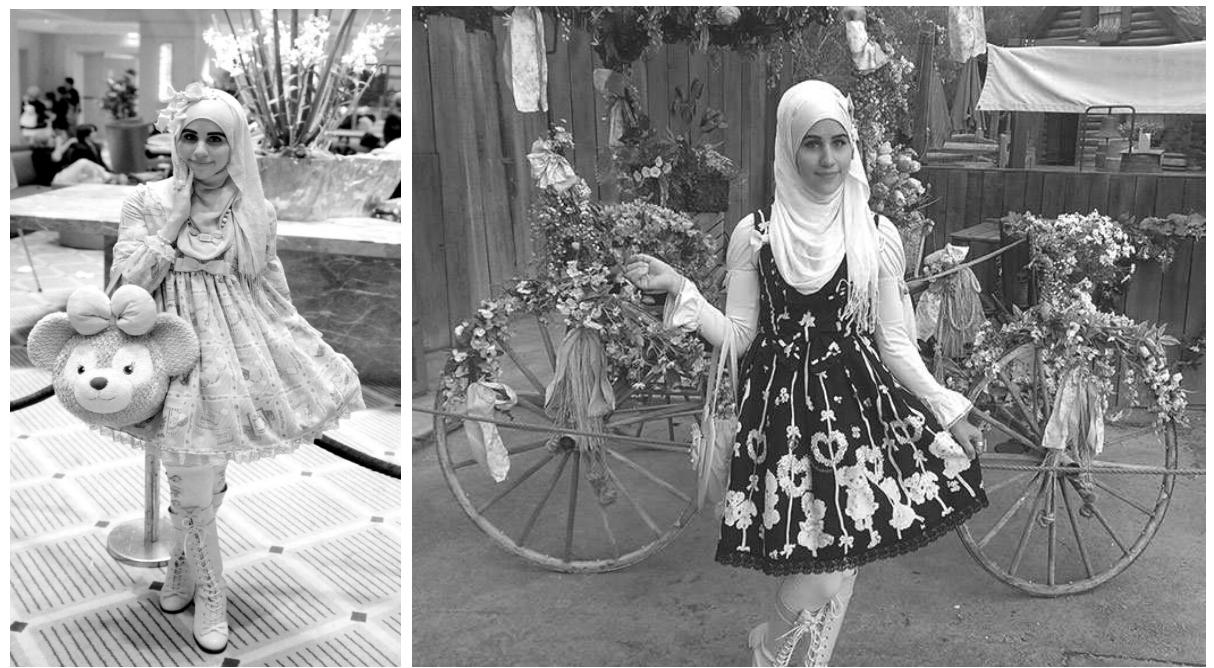

Źródło: https://www.vice.com/en_us/article/meet-the-hijabi-lolita-968 [dostep: 27.01.2017].

Przedstawiona na fotografiach popularna "muslim lolita” to Alyssa, autorka bloga The Hijabi Lolita. Przy każdej swojej stylizacji podaje nazwy sklepów, w których nabyła jej poszczególne

${ }_{11}$ Al Shatti Nouriah, Kuwaiti Style Influencer Ascia AKF Weighs in on the Middle East Blogging Community [Dostęp: 05.01.2017]. Dostępny w World Wide Web: $<$ http://bit.ly/2rlkCGf>.

12 Hijabmuslim [Dostęp: 05.01.2017]. Dostępny w World Wide Web: $<$ http:// bit.ly/2rlaeOQ>.

13 Bored Panda, Muslim Lolita Fashion Is A New Trend Inspired By Japan [Dostęp: 05.01.2017]. Dostępny w World Wide Web: <http://bit.ly/1fG3ZOH>. 
elementy ${ }^{14}$. Wymiana poglądów na temat światowych trendów, możliwa dzięki Internetowi, doprowadziła bowiem do powstania najbardziej zaskakujacych modowych połączeń. Nurt „muslim lolita" powstał $z$ fascynacji japońskim stylem lolity. Jego wielbicielki łącza $z$ hidżabem słodkie, pudrowe ubrania, torebki w kształcie misiów, gigantyczne kokardy czy wysoko sznurowane buty. Na chustę wkładaja opaski, przypinaja do niej spinki w kształcie gwiazdek i serduszek - już nie po to, by przytrzymać ją na miejscu, a jedynie ku dodatkowej ozdobie ${ }^{15}$. Fanki tego nurtu często urządzaja specjalne zloty, na których podziwiaja nawzajem swoje stroje i wymieniaja się doświadczeniami, a których organizację ułatwia im internetowa komunikacja. Nadal bowiem „muslim lolita" nie wydaja się zbyt liczne wśród społeczności muzułmańskiej. To Internet ułatwia integrację tego dość wyjątkowego środowiska.

Innym przykładem modowego bloga poświęconego obecnym trendom jest Edible Rainbows prowadzone przez brytyjska muzułmankę Noor. Przedstawia ona swoje ubrania, pisze o ulubionych torebkach lub innych akcesoriach, daje także porady początkującym muzułmańskim lolitom ${ }^{16}$.

Z kolei blogerka Basma Kahie (Basma K) eksperymentuje $\mathrm{z}$ oryginalnym makijażem, malujacc $\mathrm{np}$. swoje usta na zielono ${ }^{17}$. Anum Bashir z Kataru w wywiadzie dla „Vogue'a” wprost określa swoją modę jako „na chłopaka”. Mówi także o tym, na ile stała się ona dla niej łatwiejsza w realizacji po ślubie, odkad ma otwarty dostęp do szafy swojego męża, z której podkrada paski czy szerokie koszule ${ }^{18}$. Majacc na uwadze tradycyjny, dość wyraźny rozdział

14 The Hijab Lolita [Dostęp: 05.01.2017]. Dostępny w World Wide Web: $<$ http://bit.ly/2snUOJ2>.

15 Meet the Hijabi Lolita [Dostęp: 05.01.2017]. Dostępny w World Wide Web: $<$ http://bit.ly/2rpBP3t>.

16 Edible rainbows - blog [Dostęp: 05.01.2017]. Dostępny w World Wide Web: $<$ http:// myediblerainbows.blogspot.co.uk/>.

17 Basma_K Fashion - blog [Dostęp: 05.01.2017]. Dostępny w World Wide Web: $<$ https://www.instagram.com/basma_k/>.

18 This Qatar Art and Fashion Consultant Is Redefining Desert Style, red. M. Carlos [Dostęp: 05.01.2017]. Dostępny w World Wide Web: <http://bit.ly/ 2rTXJMM>. 
$\mathrm{w}$ islamie na to, co męskie i na to, co kobiece, jest to deklaracja dość odważna.

Prócz całkowicie nowatorskich, szalonych pomysłów i nowych trendów, blogi zawieraja także wiele codziennych, praktycznych porad dla muzułmanek. Na przykład na themuslimgirl.com 19 można przeczytać miniporadnik, w jaki sposób, pomimo noszenia hidżabu czy ubrań z długimi rękawami, zadbać o chłodzenie organizmu podczas upalnych dni: jakie nosić kroje strojów, który materiał jest wówczas najwłaściwszy na chusty albo w których popularnych sieciowych sklepach odzieżowych znaleźć można skromne ubrania.

Same muzułmanki wskazuja bowiem na to, że część ubrań przez nie noszonych jest typowo „muzułmańskimi”, które jako takie zostały uszyte i można je nabyć w specjalnych sklepach, w Internecie czy oczywiście w krajach o znacznym odsetku wyznawców islamu. Ale jest też mnóstwo ogólnie dostępnych ubrań w znanych sieciówkach, które można poddać pewnego rodzaju „islamizacji”, jak określa to autorka bloga caribmuslimah.wordpress.com ${ }^{20}$.

Oprócz tworzenia blogów muzułmanki publikują także zdjęcia swoich stylizacji na Instagramie. Piękne, artystyczne fotografie to często w równej mierze sztuka, jak i modowe wskazówki. One również, podobnie jak blogi, zdobywają całe rzesze stałych fanów. Na przykład wspomniana już Ascia Al Faraj w 2016 r. na swoim koncie na Instagramie dobiła do grona 1,9 mln „obserwujacych”, a więc stałych fanów jej profilu ${ }^{21}$.

Muzułmanki prowadzą również tematyczne strony internetowe oraz fora dyskusyjne. Co ważne, większość treści jest udostępnianych w sieci całkowicie za darmo. Oznacza to, że o ile ma się dostęp do Internetu, przeglądanie na bieżąco nowych stylizacji

19 The Muslim Girl - blog [Dostęp: 05.01.2017]. Dostępny w World Wide Web: <http://themuslimgirl.com/the-muslim-girl/>.

20 A Blog Dedicated to the Stylish Muslimah [Dostęp: 05.01.2017]. Dostępny w World Wide Web: <http://bit.ly/2smbz7q>.

${ }^{21}$ Ascia_AKF - blog [Dostęp: 05.01.2017]. Dostępny w World Wide Web: $<$ http:// bit.ly/2oybNpP>. 
nic nie kosztuje. Nie trzeba już wydawać pieniędzy na drogie magazyny, drukowane na śliskim papierze. Nie jest konieczne nawet wychodzenie $z$ domu, żeby je znaleźć i kupić.

Niezwykle popularne sa też tzw. tutoriale - filmiki na YouTube, które daja jeszcze inne możliwości niż statyczne obrazy i teksty. To przede wszystkim tutaj można znaleźć „tutoriale hidżabowe" - pokazane krok po kroku sposoby na upięcie chusty w konkretny sposób. Sa to pomysły od prostych po skomplikowane. Od tych na dni, kiedy nie ma sie zbyt dużo czasu na bawienie sie spinkami $i$ szpilkami po te, kiedy chce się wyglądać wyjątkowo i oryginalnie. Dzięki filmikom muzułmanki z różnych krajów mogą wymieniać się swoimi doświadczeniami i poznawać trendy obowiazujące $\mathrm{w}$ innych zakatkach swiata, tych $\mathrm{z}$ kręgu kultury islamu i nie tylko. Ułatwieniem $z$ pewnościa jest fakt, że znaczny odsetek blogów prowadzony jest w języku angielskim, współczesnym lingua franca, rozumianym w różnych miejscach globu. Blogerki $z$ Maghrebu, podobnie jak odwołująca się do swojego berberyjskiego pochodzenia Marokanka Jamila, często pisza posty także w języku francuskim ${ }^{22}$. Dostęp do umieszczanych na nich treści i dyskusji mają zatem czytelnicy o różnym pochodzeniu. Dzięki temu o ile dawniej konkretny sposób zakrywania włosów czy twarzy mógł zdecydowanie przeważać w konkretnym miejscu świata lub też w ogóle był znany jedynie tam, o tyle dziś, dzięki sile Internetu, wiele tendencji upowszechnia się i „globalizuje”.

Jak ukazuja powyższe przykłady, modowe podpowiedzi sa dostępne już nie tylko elitarnemu gronu arabskich czy muzułmańskich kobiet. Szybsze przejrzenie dużo obszerniejszej zawartości jest możliwe w krótszym czasie. Czytelniczki nie sa już ograniczone do kilkudziesięciu stron pisma. Głosuja „polubieniami” danych profili i stron, same więc wpływaja w pewnym stopniu na prezentowane treści. Jak zostało to wspomniane na początku tekstu, w mediach społecznościowych chodzi w końcu o ich „społeczny” charakter, a więc możliwy bezpośredni wpływ

22 Miss beauty morocco - blog [Dostęp: 05.01.2017]. Dostępny w World Wide Web: <http://missbeautymorocco.blogspot.com/>. 
odbiorców na samego nadawcę treści. Dzięki Internetowi modowe inspiracje zgodne $z$ własnym gustem można mieć na wyciagnięcie ręki, sa o wiele łatwiej dostępne i stąd też o wiele bardziej popularne.

Również ogólne światowe tendencje modowe nie omijaja środowiska muzułmanów, a zwłaszcza, jak w każdym społeczeństwie, ludzi młodych. Na pewno przyczynia się do tego fakt, iż zamieszkuja oni różne państwa świata, gdzie sa bezpośrednio „wystawieni” na zmieniające się trendy, także te „zachodnie”.

Podobnie jak kiedyś na ulice zachodnich miast wylegli nagle tzw. hipsterzy, tak zjawili się „mipsterzy”. Określenie to powstało z połączenia słów „muslim” i „hipster”. Opublikowany na YouTube filmik wideo „mipsterów” - kolorowo ubranych amerykańskich muzułmanek na deskorolkach, wzbudził w mediach goraca debatę, w tym kontrowersje w samym środowisku muzułmanów ${ }^{23}$. Na jego temat wypowiadali się m.in. goście w programie „The Stream” w anglojęzycznej wersji kanału Al Jazeera. Notabene także dzięki nowoczesnym technologiom, używając połączenia poprzez Skype’a i proszac o komentarze online na Twitterze ${ }^{24}$. Prezentowanie siebie i swoich ubrań w Internecie to często nie koniec przygody dla muzułmańskich fashionistek prowadzących portale modowe. Często udaje im się przekuć swoje zainteresowanie w prawdziwy interes. Po osiagnięciu internetowej popularności część $z$ nich rozpoczyna działalność komercyjną. W ten sposób powstaja internetowe sklepy $z$ chustami czy ubraniami, niejednokrotnie sygnowane ich nazwiskiem lub pseudonimem.

Blogerki nawiąuja także kontakty biznesowe $z$ właścicielami znanych marek produktów. Zdjęcie blogerki Sobii Masood w białych tenisówkach marki Keds zostało następnie wykorzystane

23 A. Zawadzka, Mipsterz. Muzułmanki, które podbijaja internet i mówia, że hidżab może być modny, „na:Temat” [online], [Dostęp: 05.01.2017]. Dostępny w World Wide Web: <http://bit.ly/2qBt0o4>.

24 „Stream”, Al Jazeera [Dostęp: 05.01.2017]. Dostępny w World Wide Web: <http://bit.ly/IO33X9>. 
przez właścicieli tej marki25. Zainteresowanie znanych koncernów blogami modowymi prowadzonymi przez muzułmanki stawia przed nimi nowe wyzwania, zmuszając je do decyzji biznesowych. Powstaje dylemat, czy promować jedynie marki, które się lubi, czy też zgadzać się na dochodowa współpracę, która może jednak wymagać naginania się do wymagań sponsorów. Czy przekształcać swojego bloga w działalność zawodową i poświęcać mu odtąd o wiele więcej czasu, czy raczej traktować go jako niezobowiązujące hobby ${ }^{26}$.

Basma K, właścicielka butiku Basma K Collection, prowadzi internetową sprzedaż wysyłkową chust. Poszczególne egzemplarze prezentuje na zdjęciach, na których występuje w charakterze modelki 27 .

Maryam, właścicielka bloga SincerelyMaryam ${ }^{28}$, sprzedaje swoje produkty poprzez stronę Cover3329, której nazwa pochodzi od połączenia angielskiego słowa cover, oznaczającego "zakrycie”, i numeru 33, odwołującego się do 33. sury Koranu, mówiącej m.in. o zakrywaniu się kobiet.

Leena Asad, której rodzina ma palestyńsko-amerykańskie korzenie, na Instagramie fotografuje się także w hidżabie na siłow$\mathrm{ni}^{30}$, a na swoim blogu pisze o tym, że jest pielęgniarka asystujaca przy porodach ${ }^{31}$.

\footnotetext{
25 Ismat Sarah Mangla, Muslim women are taking to Instagram to show that following their religious beliefs needn't preclude style [Dostęp: 05.01.2017]. Dostępny w World Wide Web: <http://ind.pn/2rFwDcD >.

26 Ibidem.

27 Basmak Collection [Dostęp: 05.01.2017]. Dostępny w World Wide Web: $<$ http:/ / bit.ly/2rpR1NU>.

28 Maryam [Dostęp: 05.01.2017]. Dostępny w World Wide Web: <http://www. sincerelymaryam.com/>.

29 Hijabi [Dostęp: 05.01.2017]. Dostępny w World Wide Web: <http://www.cover33.com $/>$.

30 With Love Lene [Dostęp: 05.01.2017]. Dostępny w World Wide Web: <https://www.instagram.com/withloveleena>.

31 Leena [Dostęp: 05.01.2017]. Dostępny w World Wide Web: <http://www.withloveleena.com/>.
} 
Ibtihaj Muhammad, zajmująca się prowadzeniem bloga o modzie i sklepu LouellaShop ${ }^{32}$, była pierwszą amerykańska zawodniczką w hidżabie, która walczyła w olimpiadzie w Rio w 2016 r. w turnieju szablistek. Zdobyła braz.

Anum Bashir na swoim portalu Desert Mannequin ${ }^{33}$ przedstawia sylwetki młodych projektantów $z$ Bliskiego Wschodu, przeprowadza $z$ nimi wywiady i prezentuje ich prace. Nie jest zatem, jak wiele innych blogerek, skupiona przede wszystkim na sobie, lecz próbuje też pomóc innym osobom poruszającym się w branży odzieżowej.

$Z$ cała pewnością można stwierdzić, że działalność muzułmanek w obszarze ich zainteresowan daje im nowe doświadczenia zawodowe, doprowadza do ich ekonomicznego uniezależnienia i aktywności na rynku pracy. Aktywności, która nie stoi w sprzeczności nawet $z$ tradycyjnie pojmowana rola kobiety $\mathrm{w}$ rodzinie. Sklep w wirtualnej rzeczywistości można prowadzić bez wychodzenia do biura, mając jednocześnie na oku dom i dzieci. Łatwiej zatem przekonać do tego męża czy ojca. Ascia AKF, wspomniana wcześniej blogerka $z$ Kuwejtu, występuje na swoich zdjęciach razem $z$ mężem czy dzieckiem, a więc ciesząc się wsparciem rodziny. Ona także otworzyła sklep w Internecie ${ }^{34}$. Muzułmanki, które zdecydowały się na założenie podobnego interesu, często sa pozytywnym źródłem inspiracji dla swoich koleżanek, również $\mathrm{w}$ dziedzinach niezwiąanych tylko i wyłącznie $z$ modą. Znane blogerki urastaja bowiem do roli mentorek, prawdziwych guru. Ruma Begum, blogerka $z$ Detroit, wspomina np., że wiele młodych kobiet dopytuje ja, czy hidżab powstrzymuje ja przed robieniem tego, na co ma ochotę35.

32 Louella Shop [Dostęp: 05.01.2017]. Dostępny w World Wide Web: <https://www.instagram.com/LouellaShop>.

33 Desert Mannequin [Dostęp: 05.01.2017]. Dostępny w World Wide Web: <http://www.desertmannequin.com>.

34 Ascia_AKF - blog [Dostęp: 05.01.2017]. Dostępny w World Wide Web: $<$ http:// bit.ly/2oybNpP>.

35 Meet the Hijabi Fashionistas of Instagram: Chic Muslim Women Share Their Modest Style on Social Media, red. I.S. Mangla [Dostęp: 05.01.2017]. Dostępny w World Wide Web: <http://bit.ly/2eW9FEb>. 
Prowadzenie dobrze prosperującego biznesu czy popularnego bloga może także wpływać na zwiększenie poczucia własnej wartości u ich pomysłodawczyń lub w społeczności muzułmanek jako takiej. Okazuje się, że to, co muzułmanki mają do zaoferowania, znajduje rzesze odbiorców. Ktoś chce oglądać zdjęcia ich stylizacji, komentować ich ubrania oraz kupować ich projekty.

Częściowo pod wpływem podobnych inicjatyw to już nie muzułmanki dostosowuja trendy mody do swoich wymagań, ale często to właśnie nowe trendy wynikaja wprost $z$ ich potrzeb. Staja się one pełnoprawnymi klientkami, dla których tworzone sa oddzielne kolekcje nawet najbardziej luksusowych marek, od poczatku zaplanowane jako spełniajace ich wymagania. Sławni projektanci zauważyli gigantyczny rynek o specyficznych potrzebach i postanowili $z$ tego skorzystać. Można zatem powiedzieć, że podpatrywanie trendów zachodzi dziś w obu kierunkach. $Z$ jednej strony muzułmanki, także dzięki Internetowi, dowiaduja się o ostatnich nowinkach i włączaja je do swojego stylu. $Z$ drugiej zaś sławni projektanci czy przedsiębiorcy z sektora odzieżowego moga śledzić aktualne upodobania wśród społeczności muzułmanek i dostosowywać swoje kolekcje pod ich gusta. To poczucie dumy i docenienia zarówno jako autorek odbieranych pozytywnie treści, jak i pełnoprawnych klientek jest bardzo ważne dla samych zainteresowanych, ale pokazuje też ich mniej znaną opinii publicznej stronę. Muzułmanka $z$ modowego profilu na Instagramie czy Twitterze to często pewna siebie, nowoczesna kobieta XXI w., która swoje stroje prezentuje w połączeniu ze szpilkami podczas podróży po Europie, wizyt w luksusowych restauracjach $\mathrm{i}$ kawiarniach lub $\mathrm{w}$ drogich butikach. Dian Pelangi $z$ Indonezji ma już ponad $4 \mathrm{mln}$ obserwujących ją odbiorców na Instagramie. Wśród jej fotografii znaleźć można zarówno te $z$ pokładu samolotu, $z$ wieżą Eiffle'a w tle, jak i u boku mera Paryża Anne Hidalgo 36 .

36 Dianpelagi [Dostęp: 05.01.2017]. Dostępny w World Wide Web: $<$ https://www.instagram.com/dianpelangi/>. 
Można zatem powiedzieć, że powstanie internetowego ruchu modowego wśród społeczności muzułmańskiej przyczynia się do walki ze stereotypowym wizerunkiem kobiety muzułmanki, która spowita jest w szare, obszerne, bezkształtne ubrania. Która zawsze nosi hidżab jedynie ze względu na to, że została do tego zmuszona przez ojca czy męża, a najchętniej pozbyłaby się go przy pierwszej nadarzającej się ku temu okazji. Żyjemy w czasach obrazu. Największa siłę oddziaływania maja bodźce wizualne. Wydaje się więc, że rola Internetu w przekonywaniu opinii publicznej o niejednorodności środowiska muzułmanek jest nie do przecenienia.

Chusta, która dawniej była przede wszystkim elementem kulturowym, łaczonym $z$ tradycją i religia, stała się tym samym elementem elegancji i szyku. Jej wzór czy sposób wiązania może być zgodny $z$ ostatnim krzykiem mody lub też nie. Hidżaby stają się dla niektórych dobrze przemyślanymi, stylowymi akcesoriami, a także narzędziem kreowania swojego wizerunku według własnych upodobań estetycznych.

Same muzułmanki w rozmowach twierdza, że hidżab (chusta zasłaniajaca włosy) nie jest żadnym wyrazem zniewolenia, lecz poczuciem własnej tożsamości. Łączony jest $z$ najlepszymi strojami światowych marek. Saudyjki wypowiadaja się, że nigdy w życiu by $z$ niego nie zrezygnowały, ponieważ jest to dla nich sposób na pokazanie się: kim jestem i w co wierzę. Dlatego też w ostatnich latach gwałtownie wzrosła liczba kobiet noszacych chustę w krajach muzułmańskich. Możemy przeczytać, że światowi specjaliści modowi są zgodni, iż teraz coraz częściej zwracaja się do klienta muzułmańskiego, ponieważ obecnie największe pieniądze sa w krajach arabskich. Kiedyś projektanci zabiegali o bogatych Amerykanów 37 .

Modelki prezentuja markowe hidżaby w połączeniu $z$ torebkami czy okularami przeciwsłonecznymi, które tak samo dobrze prezentuja się z produktami z głównej, „niemuzułmańskiej” linii.

37 M. Murański, M. Urzędowska, Świat mody to nie tylko Zachód. Islamic Fashion Festival w Kuala Lumpur, "Gazeta Wyborcza” [online] [Dostęp: 05.01.2017]. Dostępny w World Wide Web: <http://bit.ly/2rUpyVs>. 
Również chusta, pierwotnie sprzedawana w roli hidżabu, w rękach niemuzułmanki może stać się zwykłą apaszką. Przy okazji warto nadmienić, że od czasu do czasu zachodnia moda także przeżywa zafascynowanie Orientem i ubiera modelki w turbany lub zwiewne tuniki. Normy religijne czy społeczne strojów z kręgu kultury islamu staja się zwykłymi trendami, pozbawionymi jakichkolwiek odniesień do religii.

$\mathrm{Na}$ tej podstawie można stwierdzić, iż kobiety z kręgu kultury arabsko-muzułmańskiej niczym nie różnią się od innych kobiet. Uwielbiaja zarówno modę, jak i zakupy. Domy mody w Paryżu i Mediolanie zauważaja komercyjny potencjał w ubiorze dla muzułmanek, uwzględniajacc w swych projektach nowe trendy w modzie, jak i wartości religijne ${ }^{38}$.

Podsumowujac, muzułmanki, tak samo jak Europejki, podażaja za nowoczesnością i trendami w modzie. Noszenie hidżabu na Zachodzie często uznawane jest za przejaw dyskryminacji. Można porównać to do tego, że kobieta noszaca długa spódnicę jest gorzej traktowana od tej, co nosi krótka, dlatego jest to błędne myślenie. Muzułmanki chca być tak samo modne i nowoczesne, jak reszta kobiet świata. Każda kultura posiada swoje tradycje, które powinny się szanować, dodając od siebie coś nowego.

\section{Bibliografia}

\section{Opracowania}

Hamer Hanna, Demon nietolerancji, Warszawa: WSIP, 1994, ISBN 8302-05560-3.

Jurek Lidia, Teoria transferu kulturowego $i$ jej zastosowanie $w$ badaniach historii społecznej [w:] Studia z Historii Społeczno-Gospodarczej XIX i XX wieku, Łódź: Uniwersytet Łódzki, 2009.

Machut-Mendecka Ewa, Kobieta bez zasłony. Muzułmanka w świetle wiary i kultury [w:] Być kobieta w Oriencie, red. Danuta Chmielowska, Barbara Grabowska, Ewa Machut-Mendecka, Warszawa: Dia$\log , 2001$.

\footnotetext{
38 Ibidem.
} 
Kobiety krajów pozaeuropejskich wobec problemów współczesności, red. Anna Mrozek-Dumanowska, Warszawa: PAN, 1995, ISBN 8385810935.

Kłodkowski Piotr, Wojna światów, o wartości iluzji uniwersalnych, Kraków: Znak, 2000, ISBN 83-240-0179-4.

Koran ( $z$ arabskiego przełożył i komentarzem opatrzył J. Bielawski), wyd. IV, Warszawa: PIW, ISBN 978-83-06-03078-5.

German Culture in Nineteenth-century America: Reception, Adaptation, Transformation, red. Lynne Tatlock, Matt Erlin, New York: Camden House, 2005.

Wiebke Walther, Kobieta $w$ islamie, Warszawa: Wydawnictwo Artystyczne i Filmowe, 1980, ISBN 978-83-60904-47-3.

\section{Źródła internetowe}

Al Shatti Nouriah, Kuwaiti Style Influencer Ascia AKF Weighs in on the Middle East Blogging Community [Dostęp: 05.01.2017]. Dostępny w World Wide Web: <http://bit.ly/2rlkCGf>.

Ascia_AKF - blog [Dostęp: 05.01.2017]. Dostępny w World Wide Web: $<$ http://bit.ly/2oybNpP>.

Basma_K Collection [Dostęp: 05.01.2017]. Dostępny w World Wide Web: <http:/ / bit.ly/2rpR1NU>.

Basma_K Fashion - blog [Dostęp: 05.01.2017]. Dostępny w World Wide Web: <https://www.instagram.com/basma_k/>.

Bored Panda, Muslim Lolita Fashion Is A New Trend Inspired By Japan [Dostęp: 05.01.2017]. Dostępny w World Wide Web: <http://bit.ly/ $1 \mathrm{fG} 3 \mathrm{ZOH}>$.

Carib Muslima, A Blog Dedicated to the Stylish Muslimah [Dostęp: 05.01.2017]. Dostępny w World Wide Web: <http://bit.ly/ $2 \mathrm{smbz} 7 \mathrm{q}>$.

Desert Mannequin [Dostęp: 05.01.2017]. Dostępny w World Wide Web: <http:/ /www.desertmannequin.com>.

Dianpelagi [Dostęp: 05.01.2017]. Dostępny w World Wide Web: <https://www.instagram.com/dianpelangi>.

Dolce \& Gabbana's Embellished Hijabs and Abayas Are Great News for Muslim Women - When Will Other Brands Follow Suit?, red. Yotka Steff [Dostęp: 05.01.2017]. Dostępny w World Wide Web: $<$ http:/ / bit.ly/2qA8jJ2>.

Edible rainbows - blog [Dostęp: 05.01.2017]. Dostępny w World Wide Web: <http:/ / myediblerainbows.blogspot.co.uk/>. 
Hijabi [Dostęp: 05.01.2017]. Dostępny w World Wide Web: $<$ http://www.cover33.com>.

Hijabmuslim [Dostęp: 05.01.2017]. Dostępny w World Wide Web: $<$ http:/ / bit.ly/2rlaeOQ>.

International Islamic Fashion Festival, Discover the beauty of modesty [Dostę: 05.01.2017]. Dostępny w World Wide Web: <http://bit.ly/ $2 \mathrm{r} 16 \mathrm{KvN}>$.

Ismat Sarah Mangla, Muslim women are taking to Instagram to show that following their religious beliefs needn't preclude style [Dostęp: 05.01.2017]. Dostępny w World Wide Web: <http://ind.pn/ $2 \mathrm{rFwDcD}>$.

Leena [Dostęp: 05.01.2017]. Dostępny w World Wide Web: <http:/ /www.withloveleena.com>.

Louella Shop [Dostęp: 05.01.2017]. Dostępny w World Wide Web: <https://www.instagram.com/LouellaShop>.

Maryam [Dostęp: 05.01.2017]. Dostępny w World Wide Web: $<$ http:/ / www. sincerelymaryam.com/>.

Meet the Hijabi Fashionistas of Instagram: Chic Muslim Women Share Their Modest Style on Social Media, red. Ismat Sarah Mangla [Dostęp: 05.01.2017]. Dostępny w World Wide Web: <http://bit.ly/ $2 \mathrm{eW} 9 \mathrm{FEb}>$.

Meet the Hijabi Lolita [Dostęp: 05.01.2017]. Dostępny w World Wide Web: <http: / / bit.ly/2rpBP3t>.

Meyer Henry, Harrods liczy na zyski $z$ islamskiej mody [Dostęp: 20.01.2017]. Dostępny w World Wide Web: <http://bit.ly/ $2 \mathrm{rpyb} 9 \mathrm{~N}>$.

Miss beauty morocco - blog [Dostęp: 05.01.2017]. Dostępny w World Wide Web: <http://missbeautymorocco.blogspot.com/>.

Murański Maciej, Urzędowska Marta, Świat mody to nie tylko Zachód. Islamic Fashion Festival w Kuala Lumpur, "Gazeta Wyborcza” [online] [Dostęp: 05.01.2017], Dostępny w World Wide Web: <http://bit.ly/2rUpyVs>.

Stream Al Jazeera [Dostęp: 05.01.2017]. Dostępny w World Wide Web: $<$ http:/ / bit.ly/IO33X9>.

The Hijab Lolita [Dostęp: 05.01.2017]. Dostępny w World Wide Web: $<$ http:/ / bit.ly/2snUOJ2>.

The Muslim Girl - blog [Dostęp: 05.01.2017]. Dostępny w World Wide Web: <http://themuslimgirl.com/the-muslim-girl/>. 
This Qatar Art and Fashion Consultant Is Redefining Desert Style, red. Marjon Carlos [Dostęp: 05.01.2017]. Dostępny w World Wide Web: <http:/ / bit.ly/2rTXJMM>.

With Love Lene [Dostęp: 05.01.2017]. Dostępny w World Wide Web: <https://www.instagram.com/withloveleena>.

Zawadzka Aleksandra, Mipsterz. Muzułmanki, które podbijaja internet i mówia, że hidżab może być modny, „na:Temat” [online] [Dostęp: 05.01.2017]. Dostępny w World Wide Web: <http://bit.ly/ 2qBt0o4>. 